\title{
External Compression Headache
}

National Cancer Institute

\section{Source}

National Cancer Institute. External Compression Headache. NCI Thesaurus. Code C117083.

Headache resulting from pressure applied to the cutaneous nerves of the head. 